\title{
PENINGKATAN KESEJAHTERAAN MASYARAKAT DESA SUKOLILO MELALUI PEMANFAATAN LIMBAH KERTAS MENJADI PRODUK BERNILAI EKONOMI
}

\author{
Tri Andari ${ }^{1}$ dan Restu Lusiana ${ }^{2}$ \\ 1,2Prodi Pendidikan Matematika, FPMIPA, IKIP PGRI MADIUN \\ Email: trianmath03@gmail.com
}

\begin{abstract}
The purpose of this training is the training participants can process the waste of paper and then process it into recycled paper ready for sale to the basic ingredients of craft and production of handicrafts made from recycled paper, master the skills and attitudes include the training of administrative, entrepreneurial management, organization, and marketing. The training activities carried out in the village Sukolilo Jiwan subdistrict, Madiun Regency. This activity uses two methods of approach, the first separation of training activities and the processing of waste paper and paper-based creative production. And the second is training and mentoring organization, management and entrepreneurship. Assistance activities primarily intended to increase the value of selling their production of processed waste so it can be accepted with a high value in the market. Training is done in six stages, namely the preparatory stage, the introduction stage, the stage of establishment of the system, stages of creative production, sales stage, and the stage of development. The results of the activities are 1) most of the trainees can follow every stage of the training given to the good, but there are some stages that have not been implemented, namely the development phase in view of the time constraints, 2) Kesejahateraan villagers Sukolilo increased through the utilization of waste paper into recycled paper which is then processed into a product of creative economic value.
\end{abstract}

\section{Keywords:}

Abstrak. Tujuan dari kegiatan pelatihan ini adalah peserta pelatihan dapat mengolah sampah kertas kemudian memprosesnya menjadi kertas daur ulang siap jual untuk bahan dasar kerajinan dan produksi hasil kerajinan berbahan dasar kertas daur ulang, menguasai keterampilan dan sikap meliputi pelatihan administrasi, manajemen kewirausahaan, organisasi, dan pemasaran. Kegiatan pelatihan dilakukan di Desa Sukolilo Kecamatan Jiwan Kabupaten Madiun. Kegiatan ini menggunakan dua metode pendekatan, yang pertama kegiatan pelatihan pemisahan serta pengolahan limbah kertas dan produksi kreatif berbahan dasar kertas. Dan yang kedua adalah pelatihan dan bimbingan organisasi, manajemen dan kewirausahaan. Kegiatan Pendampingan terutama ditujukan untuk meningkatkan nilai hasil jual produksi olahan sampah sehingga bisa diterima dengan nilai tinggi di pasar. Pelatihan dilakukan dalam enam tahapan yaitu tahap persiapan, tahap pengenalan, tahap pembentukan sistem, tahap produksi kreatif, tahap penjualan, dan tahap pengembangan. Adapun hasil pelaksanaan kegiatan adalah 1) sebagian besar peserta pelatihan dapat mengikuti setiap tahapan pelatihan yang diberikan dengan baik, namun ada beberapa tahap yang belum terlaksana yaitu tahap pengembangan mengingat keterbatasan waktu, 2) Kesejahateraan masyarakat desa Sukolilo meningkat melalui pemanfaatan limbah kertas menjadi kertas daur ulang yang kemudian diolah menjadi produk kreatif yang bernilai ekonomi.

Kata kunci: Kesejahteraan Masyarakat, Limbah Kertas, Produk ekonomi 


\section{PENDAHULUAN}

\section{Analisis Situasi}

Melambungnya harga-harga kebutuhan pokok membuat banyak wanita saat ini tidak hanya menjadi ibu rumah tangga namun juga ikut membantu suami dengan bekerja, demi mencukupi kebutuhan keluarga. Banyak ibuibu terutama di Desa Sukolilo Kecamatan Jiwan yang bekerja di sektorinformal. Hal ini dikarenakan Desa Sukolilo merupakan daerah yang sedang berkembang. Motif ekonomi membuat banyak penduduk asli termarginalkan dengan seiring berkembangnya dan muncul perumahan-perumahan di daerah Jiwan. Untuk menambah penghasilan keluarga, ibuibu penduduk asli membantu suami bekerja di perumahan-perumahan sebagai pembantu rumah tangga. Mereka bekerja dari pagi sampai siang/sore untuk membantu pekerjaan bersihbersih, cuci, setrika, memasak, merawat anak, antar jemput sekolah anak dan penunggu rumah. Sebagian besar ibu-ibu ini berpendidikan rendah dan tidak memiliki keterampilan. Namun budaya gotong-royong dan sistem kekerabatan yang erat masih mendominasi masyarakat marginal Desa Sukolilo. Salah satunya dengan keaktifan mereka berkumpul di pengajian dan arisan rutin setiap bulannya.

Sampah merupakan konsekuwensi dari adanya aktivitas manusia. Sejalan dengan peningkatan penduduk dan gaya hidup sangat berpengaruh pada volume sampah. Seperti juga di daerah lain, Desa Sukolilo juga memiliki masalah yang menyangkut sampah. Berdasarkan informasi yang diperoleh dari kantor Desa Sukolilo Kecamatan Jiwan Kabupaten Magetan (2015), volume sampah di Desa Sukolilo dari tahun ke tahun makin meningkat. Sampah tersebut mayoritas adalah sampah rumah tangga yang terdiri dari berbagai bahan organik dan anorganik. Sampah organik diantaranya daun-daunan, sayuran dan buah-buahan yang terbuang dari proses memasak, serta makanan sisa (nasi basi, tulang ikan, bungkus daridaun dan lain-lain), sampah anorganik diantaranya botol kaca bekas, kertas, kaleng kertas, bekas kemasan kue, rangka meja, besi, dan rangka beton, berbagai plastik bekas wadah shampo, deterjen, ember, dan lainnya.

Interaksi yang tinggi ibu-ibu ini dengan sampah jenis sampah rumah tangga menjadikan kegiatan pengolahan sampah sangat tepat untuk diimplementasikan. Berkenaan dengan itu, kegiatan pengabdian ini ditujukan kepada ibu-ibu untuk mengisi waktu luangnya dengan kegiatan bersama mengolah sampah sehingga dapat menghasilkan tambahan uang sehingga menumbuhkan jiwa kewirausahaan. Padahal menurut Usman (Suryana, 2006) memiliki kemampuan dalam menggunakan dan mengkombinasikan sumber daya seperti keuangan, material, tenaga kerja, ketrampilan untuk menghasilkan produk, proses produksi, bisnis, organisasi usaha baru penting untuk dapat secara bersama-sama membentuk suatuusaha bersama dalam rangka meningkatkan taraf kehidupan keluarga. Sampah yang mudah ditemui di lingkungan serta bagaimana mengelolanya, menjadi inti dari kegiatan ini. Untuk itu peserta didik membutuhkan pelatihan agar memiliki kemampuan untuk mengolah dan menjadikannya usaha untuk meningkatkan pendapatan. Keterampilan mengelola dan meningkatkan nilai ekonomis antara lain meliputi mengumpulkan dan memilah kemudian meprosesnya untuk bahan dasar kerajinan.

Berdasar hasil pengamatan Tim Iptek bagi Masyarakat (IbM), ditemukan permasalahan tambahan yang secara teoritis menunjukkan selain interaksi yang tinggi khususnya terhadap keberadaan sampah rumah tangga dan waktu senggang yang belum dimanfaatkan secara optimal untuk menambah penghasilan. Permasalahan tambahan ini didapat dari penggalian 
dan interview dengan beberapa calon peserta didik, berkenaan dengan kurangnya motivasi untuk melanjutkan kegiatan pelatihan yang dilakukan meskipun mereka memahami manfaat yang ditimbulkan. Hal ini karena belum munculnya kebutuhan dan motivasi yang kuat untuk mengoptimalkan pengetahuan yang dimiliki. Temuan ini sebenarnya tidak jauh berbeda dengan hasil penelitian Arifah (2006) mengenai kewirausahaan bagi perempuan pengrajin keripik pisang, pengrajin bordir, dan pengrajin tas mendong di kabupaten Ciamis yang menyimpulkan bahwa pelatihan keterampilan kewirausahaan akan memiliki efektivitas yang tinggi apabila dilakukan secara periodik. Mulyana(2004) dalam studinya mengenai pembelajaran partisipatif dalam usaha budidaya stroberi pada kelompok tani Giri Saluyu di Lembang juga menambahkan bahwa tanggung jawab dan disiplin dalam belajar meningkatkan ketrampilan serta sikap kemitraan peserta belajar.

Berangkat dari dua studi diatas, dalam pengabdian masyarakat, tim IbM menekankan bentuk pelatihan berbasis kewirausahaan disertai penguatan kapasitas organisasi agar pembelajaran dapat berlangsung secara terusmenerus meskipun kegiatan pengabdian sudah berakhir. Kegiatan Iptek bagi Masyarakat ditujukan untuk meningkatkan pendapatan kegiatan ibu-ibu yang berkerja di sektor informal dan tergabung dalam pengajian dan arisan di Desa Sukolilo. Kegiatan yang dilakukan adalah berjalannya usaha simpan pinjam berbayar sampah serta produksi berbahan dasar daur ulang kertas koperasi sampah Desa Sukolilo. Adapun kegiatan IbM tersebut meliputi seperti berikut:

1. Dilakukan kegiatan pelatihan pengelolaan sampah meliputi mengolah kemudian memprosesnya menjadi kertas daur ulang siap jual untuk bahan dasar kerajinan dan produksi hasil kerajinan berbahan dasar kertas daur ulang.

2. Pembentukan koperasi simpan pinjam sampah disertai kegiatanpenguatan organisasi koperasisimpan pinjam bersama pengurus inti.

3. Dilakukan pelatihan pengembangan sumber daya manusia dalam pengetahuan keterampilan dansikap, meliputi pelatihan administrasi, manajemen kewirausahaan, organisasi, dan pemasaran.

Manfaat dari kegiatan programIbM adalah terbentuknya usahamandiri yang mampu meningkatkanpendapatan ibu-ibu pekerja informalyang tergabung dalam pengajian dan arisan Desa Sukolilo dengan mengolah sampah serta memproduksi produksi kreatif berbahan dasar kertas daur ulang. Diharapkan anggota tersebutsemakin mampu mengembangkan kegiatan produktifnya dan menarikminat anggota masyarak yang lainkedalam organisasi baru koperasisimpan pinjam sampah Desa Sukolilo.

\section{Permasalahan Mitra}

1. Bagaimanakah kegiatan pelatihan pengelolaan sampah meliputi mengolah kemudian memprosesnya menjadi kertas daur ulang siap jual untuk bahan dasar kerajinan dan produksi hasil kerajinan berbahan dasar kertas daur ulang?

2. Bagaimanakah pembentukan koperasi simpan pinjam sampah disertai kegiatan penguatan organisasi koperasi simpan pinjam bersama pengurus inti?

3. Bagaimanakah pelatihan pengembangan sumber daya manusia dalam pengetahuan keterampilan dan sikap, meliputi pelatihan administrasi, manajemen kewirausahaan, organisasi, dan pemasaran? 


\section{METODE PELAKSANAAN}

\section{Metode pendekatan yang ditawarkan}

Kegiatan ini menggunakan dua metode pendekatan, yang pertama kegiatan pelatihan pemisahan serta pengolahan limbah kertas dan produksi kreatif berbahan dasar kertas. Dan yang kedua adalah pelatihan dan bimbingan organisasi, manajemen dan kewirausahaan. Kegiatan Pendampingan terutama ditujukan untuk meningkatkan nilai hasil jual produksi olahan sampah sehingga bisa diterima dengan nilai tinggi di pasar.

\section{Rencana Kegiatan dan Prosedur Kerja}

Kegiatan program IbM tentang cara mengolah pengolahan limbah kertas dan produksi kreatif berbahan dasar kertas daur ulang siap jual dilaksanakan dengan peserta ibuibu yang tergabung dalam kelompok ibu-ibu Arisan dan pengajian yang ada di RT 08 dan RT 09 desa Sukolilo kecamatan Jiwan. Setiap satu minggusekali mereka berkumpul untuk mengadakan pengajian rutin di rumah-rumah warga secara bergantian. Sedangkan untuk acara arisan ibu-ibu diadakan setiap bulan. Kegiatan ini yang akan dimanfaatkan pula untuk memberikan edukasi cara pengolahan sampah menjadi sumber daya ekonomi. Kegiatan ini dilakukan dengan tahap-tahap sebagai berikut.

\section{Tahap Persiapan}

Pada tahap ini dilakukan survei permasalahan yang dihadapi masyarakat sasaran dan merumuskan masalah sehingga dapat dicari solusi pemecahan.

\section{Tahap Pengenalan}

Setelah ditemukan solusi, maka kemudian kelompok Ibu-ibu arisan dan pengajian diberi pelatihan tentang cara mengolah limbah kertas menjadi produk kreatif. Menurut Yahya (2005) langkah-langkah mengolah limbah kertas adalah sebagai berikut:

a. Sobek-sobek kertas bekas dan rendam di air selama 1 hari;

b. Blender kertas sampai menjadi bubur

c. Tuangkan ke dalam baskom yang berisi air dan diaduk

d. Letakkan spons di atas meja. Lalu letakkan kain yang sudah dibatasi di atasnya.

e. Saring campuran (jangan terlalu tebal) di baskom menggunakan screen sablon

f. Letakkan di atas spon yang sudah dilapisi kain dengan posisi dibalik, gosok sedikit screennya dan angkat dengan hati-hati.

g. Tutup dengan kain yang sudah dibasahi, tambah satu lapis lagi kain basah, ulangi langkah e) dan f).

h. Sesudah beberapa lapis, press dengan menaruh papan besar di atasnya dan beri pemberat (batako)

i. Biarkan selama 1 jam agar air berkurang, angkat setelah kering.

Pada tahap ini selain diberikan pelatihan juga diberikan wawasan tentang lingkungan, sehingga peserta dapat memilah sampah rumah tangga sesuai jenisnya.

3. Tahap Pembentukan Sistem

Dalam tahap ini peserta diberikan pelatihan dan dibekali materi tidak saja pengolahan limbah kertas menjadi kertas daur ulang namun sampai dengan bagaimana kertas daur ulang tersebut diproses menjadi produk kreatif sedemikian rupa sehingga laku terjual/diserap pasar. Hal ini agar ke depan tercipta sistem sehingga produk yang diolah mampu diterima pasar sehingga laku terjual. Kegiatan dimulai dengan peserta membawa limbah kertas yang 
sudah dibersihkan. Selanjutnya, kertas dipilahpilah berdasarkan kelompok warna tertentu, misalnya merah, biru, kuning, coklat, pink, dan sebagainya. Selanjutnya limbah kertas sobeksobek dan rendam di air.

Dalam kegiatan tersebut, peserta dibagikan screen sablon dengan bingkai, ember, air, blender, papan kayu, batako, setrika, kain halus, baskom, dan meja. Setelah Ibu-Ibu memiliki keterampilan cara mengolah limbah kertas menjadi bubur kertas sertata diolah menjadi produksi kreatif, untuk selanjutnya akan disosialisasikan bagaimana prosedur pengumpulan dan distribusi produk kreatif yang siap dijual.

\section{Tahap Produksi Kreatif}

Pada tahap ini, peserta dibekali kemampuan untuk mengolah limbah kertas menjadi kertas daur ulang. Selain itu peserta juga dibekali dengan kemampuan membuat kertas daur ulang menjadi produk kreatif. Beberapa produk kreatif yang akan dihasilkan diantaranya adalah lampu hias, note book, paper bag, gantungan kunci, dan kotak kado.

Dalam kegiatan ini peserta akan diberikan gambaran bagaimana cara memberikan sikap positif cara menawarkan produk kepada pasar terhadap produk kreatif yang di hasilkan, sehingga timbul motivasi untuk meningkatkan kemampuan produksi dalam mengolah limbah kertas, sehingga dapat terus berkelanjutan kepada produk-produk kreatif yang lebih baik lagi.

\section{Tahap Penjualan}

Tahap ini lebih terkonsentrasi pada peningkapatan kapasitas pengurus yang akan mengkoordinir penjualan hasil produk dari peserta kegiatan. Di sini dijelaskan bahwa produk-produkkreatif yang telah dihasilkan kemudian dikemas sedemikian rupakemudian baru dijual kesentra-sentra industri kerajinan sedangkan produksi kreatif berbahan dasar kertas akan ditawarkan dan dijual ke tokotoko, kantor-kantor, dan lain sebagainya sehingga dijembatani ke mana saja produk akan disalurkan.

Setelah mengikuti pembelajaran ini peserta kegiatan diharapkan mampu mencermati produk-produk mana sajayang banyak diserap pasar. Supaya kegiatan ini bisa tetap berjalan maka dibuat Memorandum of Understanding (perjanjian kesepakatan) antarpeserta yang diwakili oleh ketua organisasi produksi kreatif dengan mitra untuk tetap dapat bekerjasama dalam penjualan produk kreatif.

\section{Tahap Pengembangan}

Tahap ini adalah penerapan asas suistanable development program (keberlanjutan pengembangan kegiatan), artinya sebagai daya upaya agar kegiatan tetap berjalan dan berkembang secara berkelanjutan setelah program IbM berakhir. Kegiatan yang dilaksanakan adalah pengadaan program simpan pinjam didasarkan kepada prinsip-prinsip menolong diri sendiri (swadaya), tanggung jawab pribadi, demokrasi, keadilan, persamaan dan solidaritas, di samping nilai-nilai kejujuran, keterbukaan, tanggung jawab sosial dan peduli pada masyarakat yang menyangkut semua anggota. Nilai-nilai tersebut sesuai dengan lingkungan keberadaan masyarakat tempat program IbM dilaksanakan dimana suasana gotong-royong dan kekerabatan masih terjalin dengan baik.

Selain pengadaan program simpan pinjam pada kegiatan ini juga diberikan pelatihan yang meliputi materi sistem administrasi penjualan produk, klasifikasi harga produk, penentuan sisa hasil usaha, dan sistem hutang piutang. Sistem simpan pinjam pada program ini ada keunikan sendiri dimana anggota memiliki hak untuk meminjam uang namun pembayaran dilakukan dalam bentuk mengumpulkan kertas daur ulang atau produk kreatif bernilai 
jualberbahan dasar kertas daur ulang. Setiap anggota akan menerima buku tabungan program limbah kertas. Tujuan dibagikannya buku tersebut, selain untuk mengetahui besar cicilan pinjaman juga agar para peserta dapat mengetahui seberapa banyak limbah kertas yang telah ditabung. Tahap-tahap pelatihan dan pendampingan tersebut di atas, dilaksanakan oleh tim pengabdi program IbM dan diharapkan dapat menghasilkan output dan outcome sebagai berikut:

\section{a. Output}

Output dari kegiatan ini adalah meningkatnya kompetensi peserta kegiatan yang ditandai dengan indikator ranah kognitif dimana memiliki pengetahuan mengolah limbah kertas menjadi sumber daya ekonomi. Dalam ranah afektif adalah berkembangnya jiwa kewirausahaan dalam melihat peluang berkaitan dengan keberadaan limbah kertas di sekitarnya untuk dikelola menjadi kegiatan positif. Pada ranah psikomotorik peserta mampu mengaplikasi pengetahuan yang dimiliki sehingga menjadi pendapatan tambahan di tandai dengan diserapnya hasil produksi oleh pasar produksi pengolahanlimbah kertas, limbah kertas atau produksi kreatif yang dihasilkan.

\section{b. Outcome}

Pembelajaran pada program IbM ini membentuk peserta kegiatan mampu mengolah limbah kertas dan mengubahnya sehingga bernilai ekonomis sehingga terpecahkan masalah sosial yang ada seperti masalah ekonomi, lapangan kerja, masalah limbah kertas, dan lain-lain.

\section{HASIL DAN PEMBAHASAN}

Pada bab ini akan dipaparkan beberapa hal yang terkait dengan pelaksanaan program. Hal itu meliputi hasil yang dicapai dan pembahasan pelaksanaan IbM yang telah dilaksanakan

\section{Hasil Pelaksanaan Kegiatan}

1. Tahap Persiapan

Berdasarkan hasil observasi diketahui bahwa permasalahan yang ada seperti berikut:

a. Perlu dibentuk suatu kelompok yang dapat membuat produksi kreatif dari limbah kertas.

b. Kelompok yang terbentuk diharapkan produktif sehingga harapannya tidak berhenti pada pengolahan limbah kertas, tapi juga mampu memproduksi produk kreatif berbahan dasar kertas daur ulang

Tahap ini diawali dengan membentuk kelompok peserta pelatihan yang terdiri dari 10 orang. Peserta pelatihan akan diberikan pelatihan dengan memamfaatkan limbah kertas menjadi kertas daur ulang, selain itu peserta pelatihan juga diberikan pelatihan memproduksi produk kreatif berbahan dasar kertas daur ulang. Dibawah ini adalah daftar peserta pelatihan yang terbentuk.

\section{Tabel 1. Daftar Nama Peserta Pelatihan}

\begin{tabular}{cll}
\hline No. & \multicolumn{1}{c}{ Nama } & \multicolumn{1}{c}{ Pekerjaan } \\
\hline 1 & Yatini & Ibu Rumah Tangga \\
\hline 2 & Taufik Hidayati & Pedangang Grabah \\
\hline 3 & Ida & Ibu Rumah Tangga \\
\hline 4 & Yati & Ibu Rumah Tangga \\
\hline 5 & Marsum & Ibu Rumah Tangga \\
\hline 6 & Erma Rimawati & Ibu Rumah Tangga \\
\hline 7 & Waidah & Petani \\
\hline 8 & Dewi R. & Ibu Rumah Tangga \\
\hline 9 & Esti Ningtyas & Ibu Rumah Tangga \\
\hline 10 & Anis & Pedagang Es dan Rujak \\
\hline
\end{tabular}

2. Tahap Pengenalan

Pada tahap ini peserta diberikan gambaran pelatihan tentang cara mengolah limbah kertas menjadi bubur kertas yang kemudian dibuat menjadi kertas daur ulang yang akhirnya dapat menghasilkan produk kreatif yang bernilai ekonomi. 


\section{Tahap Pembentukan Sistem}

Dalam tahap ini peserta diberikan pelatihan dan dibekali materi tidak saja pengolahan limbah kertas menjadi kertas daur ulangnamun sampai dengan bagaimana kertas daur ulang tersebut diproses menjadi produk kreatif sedemikian rupa sehingga laku terjual/diserap pasar. Pelatihan ini memberikan beberapa materi yang terkait dengan pengolahan limbah kertas enjadi kertas daur ulang yang selanjutnya dibuat produk kreatif yang bernilai ekonomi. Materi yang akan disajikan dalam tahap pembentukan sistem terdiri dari5 (lima) bahasan yang masing-masing disajikan oleh anggota tim pengabdi. Berikut tabel daftar materi dan pematerinya yang telah terlaksana dalam program PPM ini.

Pelaksanaan program ini melibatkan 2 mahasiswa agar kegiatan dapat berjalan lancar. Kegiatan tanya jawab dilakukan bersamaan dengan penyajian materi. Para peserta dapat langsung berdiskusi dengan para pemateri secara langsung untuk memahamkan materi dan sharing pengalaman terkait dengan masalah yang tengah dibahas. Kegiatan ini terlaksana di rumah salah satu peserta pelatihan. Adapun foto-foto yang dapat kami ambil sebagai dokumentasi adalah sebagai berikut:

Tabel 2. Tahapan Pengenalan Pembuatan Kertas Daur Ulang

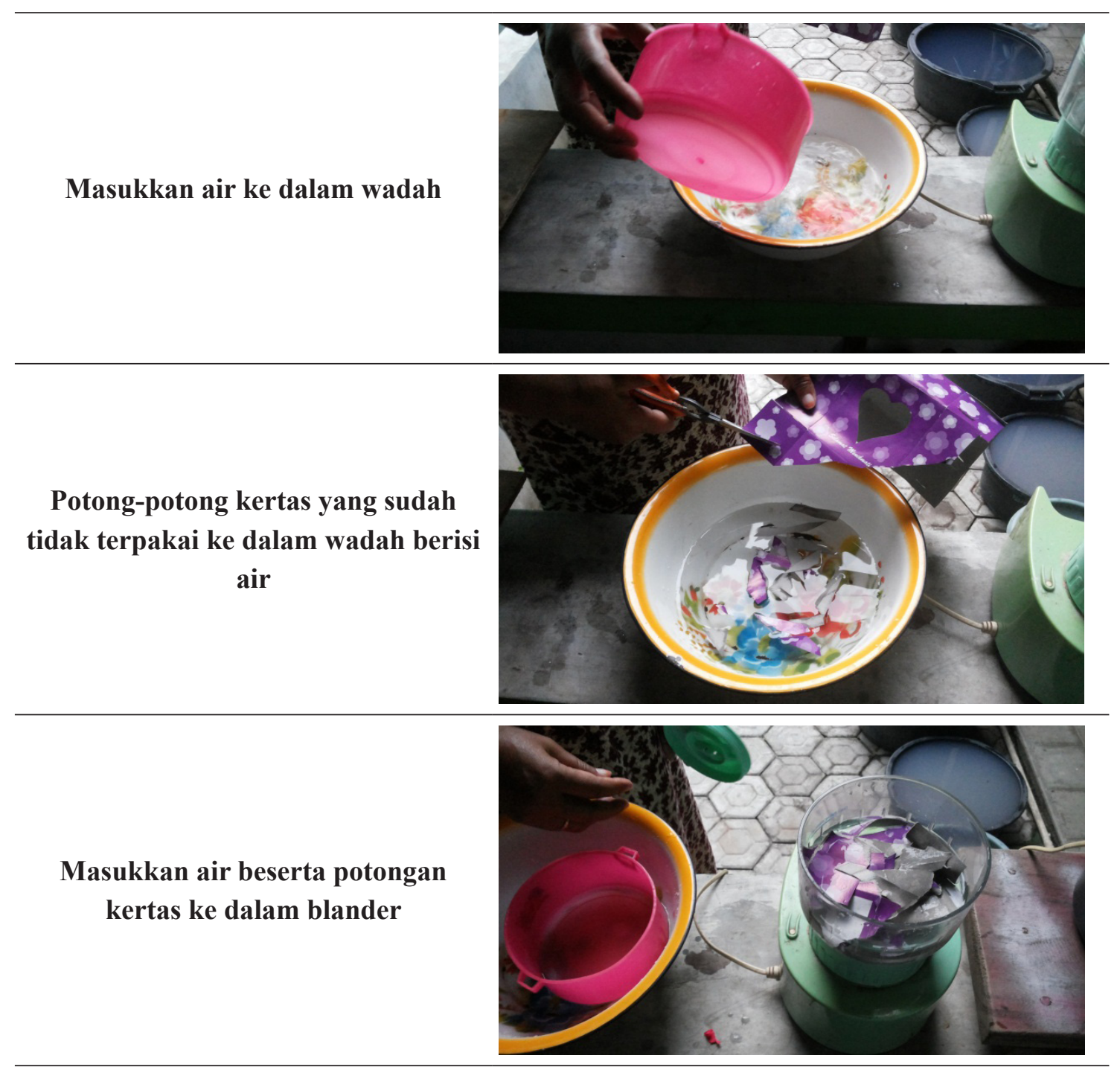


Haluskan dengan menggunakan blander

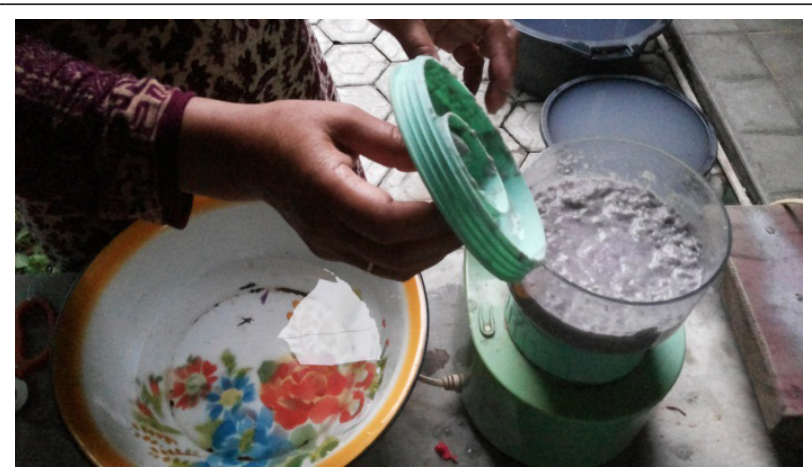

Setelah halus tuang kembali ke dalam wadah dan tambahkan air

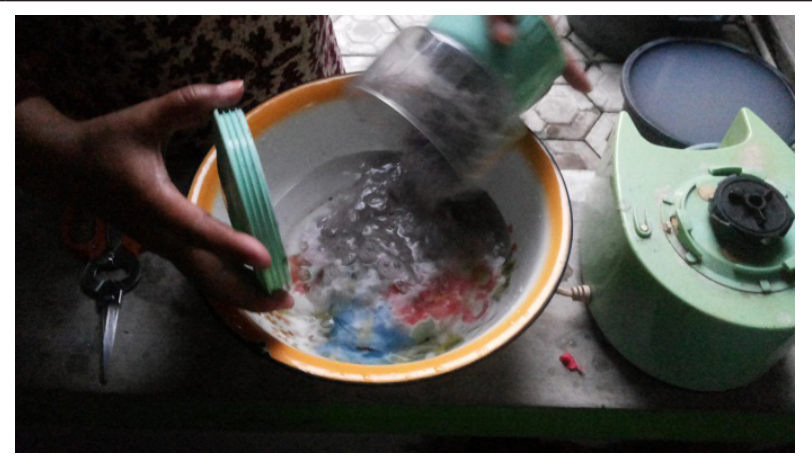

Aduk-aduk hingga rata dan tercampur

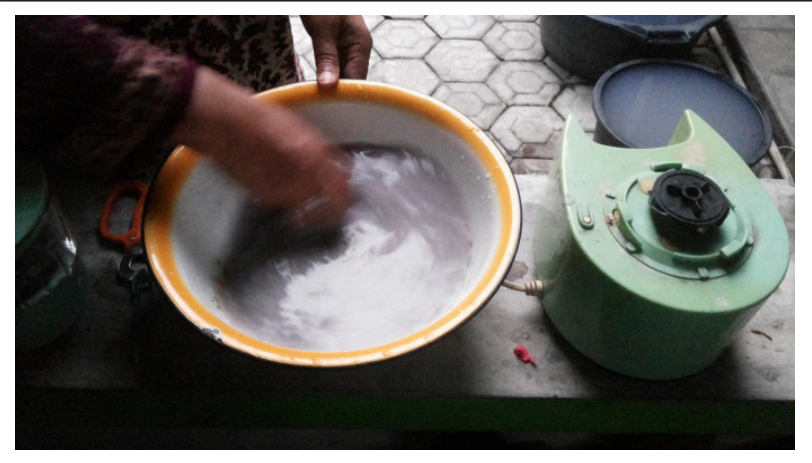

Tuangkan adonan kertas ke dalam cetakan (Screen sablon) yang sudah disiapkan

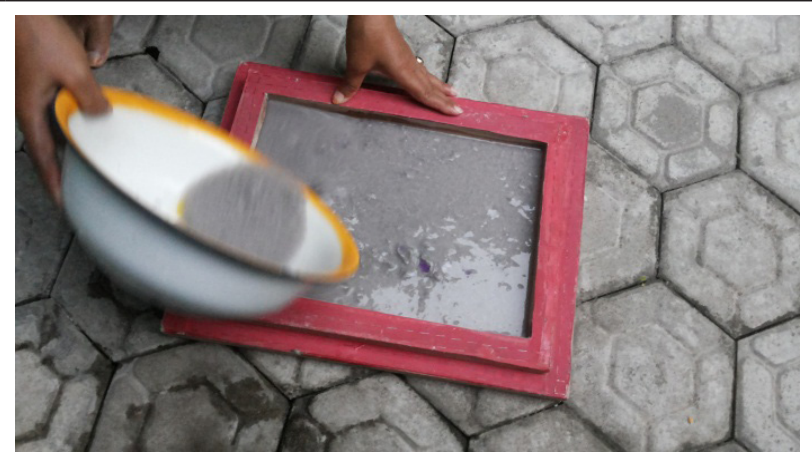

Diamkan sebentar sampai air turun

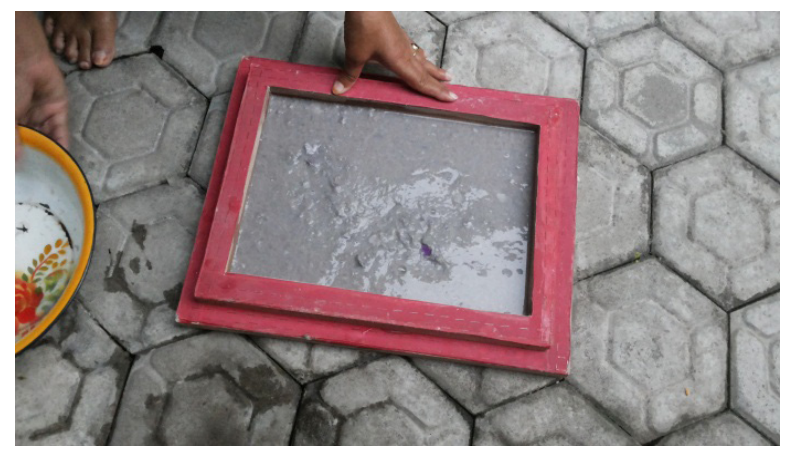


Angkat pembatas dan siap untuk di jemur
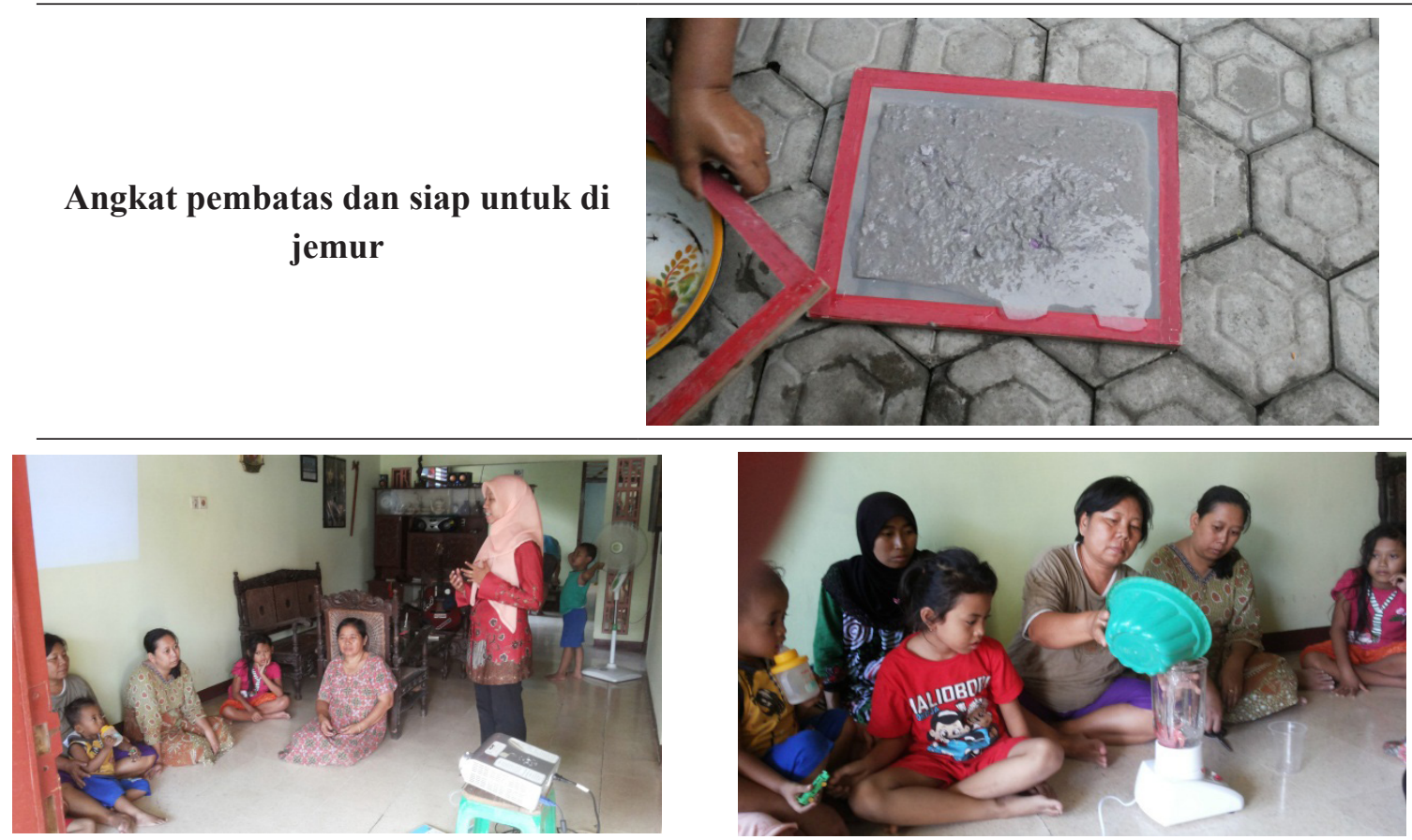

Gambar 1. Pelaksanaan Kegiatan Pembuatan Kertas Daur Ulang

4. Tahap Produksi Kreatif

Pada tahap ini, peserta dibekali kemampuan untuk mengolah limbah kertas menjadi kertas daur ulang dengan cara praktek secara langsung. Selain itu peserta juga dibekali dengan kemampuan membuat kertas daur ulang menjadi produk kreatif yang didampingi oleh tim pengabdi. Tahap ini dilaksanakan pada tanggal 6 September 2015. Beberapa produk kreatif yang dihasilkan dari tahap ini adalah sebagai berikut.

Tabel 3. Daftar Produk Kreatif

Nama Produk




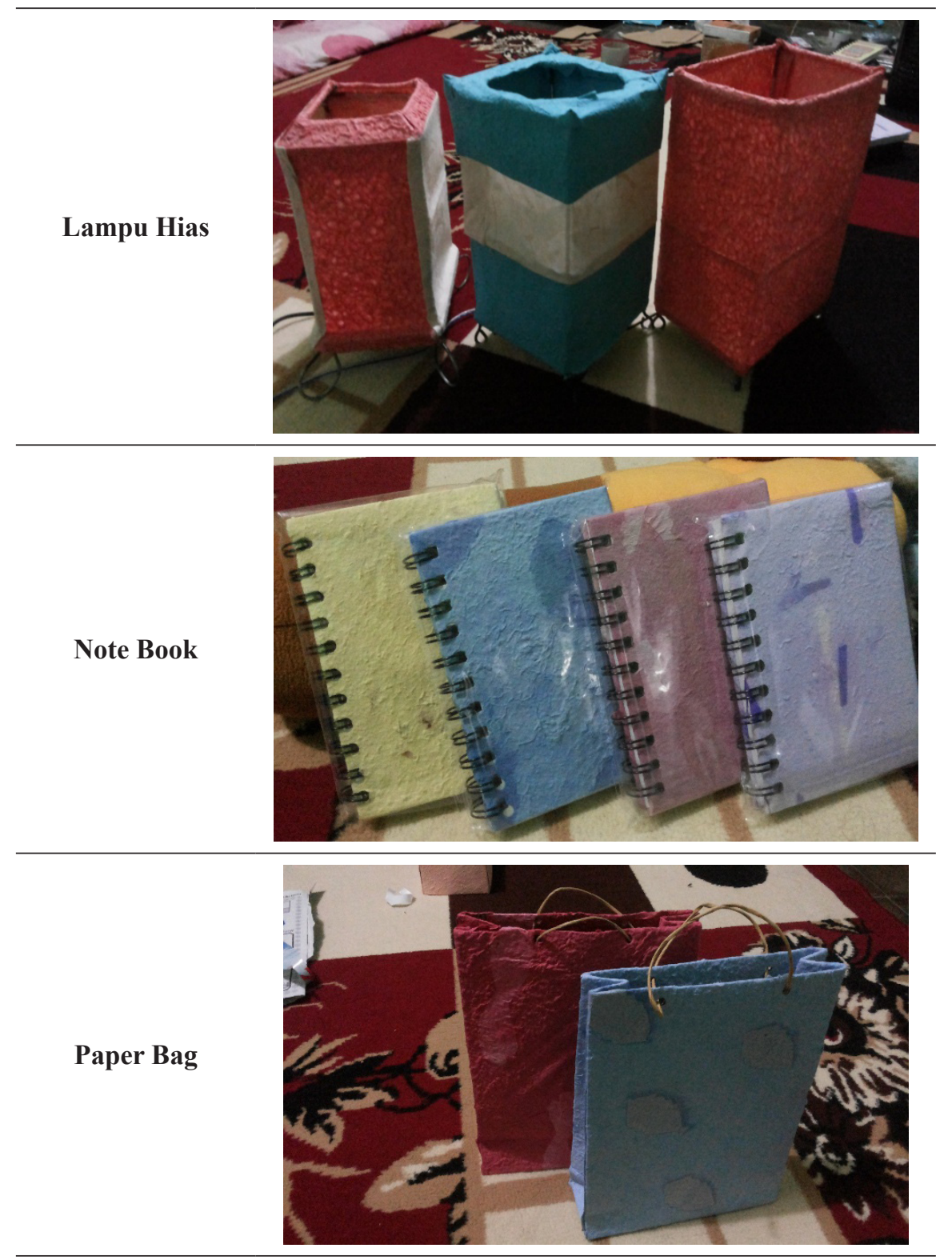

Dalam kegiatan ini peserta juga diberikan gambaran cara memberikan sikap positif dalam penawaran produk kreatif kepada pasar terhadap produk kreatif yang di hasilkan, sehingga timbul motivasi untuk meningkatkan kemampuan produksi.

\section{Tahap Penjualan}

Tahap ini lebih terkonsentrasi pada peningkatan kapasitas pengurus yang akan mengkoordinir penjualan hasil produk dari peserta kegiatan. Tahap ini dilaksanakan pada tanggal 12 September 2015.
Pada tahap ini juga dijelaskan bahwa produk-produk kreatif yang telah dihasilkan kemudian dikemas sedemikian rupakemudian baru dijual kesentra-sentra industri kerajinan sedangkan produksi kreatif berbahan dasar kertas akan ditawarkan dan dijual ke toko-toko, dan kantor-kantor. Tahap ini berlangsung mulai tanggal 12 sampai 26 September 2015.

Setelah mengikuti pembelajaran ini peserta kegiatan diharapkan mampu mencermati produk-produk mana sajayang banyak diserap pasar. Kelemahan dari tahap ini yaitu pembuatan Memorandum of Understanding 
(perjanjian kesepakatan) antarpeserta yang diwakili oleh ketua organisasi produksi kreatif dengan mitra untuk tetap dapat bekerjasama dalam penjualan produk kreatif belum dapat terwujud dikarenakan keterbatasan waktu.

\section{Tahap Pengembangan}

Tahap ini adalah tahappengadaan program simpan pinjam dan pelatihan yang meliputi materi sistem administrasi penjualan produk, klasifikasi harga produk, penentuan sisa hasil usaha, dan sistem hutang piutang. Sistem simpan pinjam pada program ini ada keunikan sendiri dimana anggota memiliki hak untuk meminjam uang namun pembayaran dilakukan dalam bentuk mengumpulkan kertas daur ulang atau produk kreatif bernilai jualberbahan dasar kertas daur ulang. Setiap anggota akan menerima buku tabungan program limbah kertas. Tujuan dibagikannya buku tersebut, selain untuk mengetahui besar cicilan pinjaman juga agar para peserta dapat mengetahui seberapa banyak limbah kertas yang telah ditabung. Namun tahap ini belum dapat terlaksana dikarenakan keterbatasan waktu.

\section{Pembahasan Pelaksanaan IbM}

Evaluasi kegiatan PPM ini dilakukan dengan beberapa cara. Evaluasi hasil dilihat dari tugas praktik para peserta yang ada. Hasil praktiknya dinilai dan hal itu menggambarkan keberhasilan materi yang telah disajikan. Selain itu, secara proses juga dicermati kinerja dan kesertaan para peserta.

Berdasarkan hasil produk berupa hasil karya seni kertas daur ulang yang terbuat dari bubur kertas, secara umum para peserta telah mengetahui telah mampu memahami materi pembuatan kertas daur ulang dari bubur kertas dengan dipahaminya aspek pengenalan bahan, alat, dan teknik, pembuatan pola desain sesuai cetakan, proses pewarnaan/finishing akhir dan pengeringan, serta mampu berpraktek membuat produk kreatif dari kertas daur ulang secara mandiri dibawah bimbingan tim pengabdi. Karya-karya yang dihasilkan peserta berupa benda pakai seperti kertas lampu hias,note book, paper bag, gantungan kunci, dan kotak kado.

Evaluasi kegiatan yang dilakukan selama proses kegiatan berlangsung, yaitu pada saat peserta kegiatan melaksanakan proses pembuatan karya. Teknik evaluasi dilakukan dengan cara observasi langsung, yaitu dengan melihat bagaimana kualitas karya yang dihasilkan. Ratarata para peserta telah mampu membuat karya dengan baik, karena teknik pembuatan kerajinan ini relatif mudah.

Berdasarkan hasil observasi, peserta pelatihan yang sebagian besar berprofesi sebagai ibu rumah tangga mampu memanfaatkan limbah kertas menjadi kertas daur ulang yang kemudian diolah menjadi produk kreatif yang bernilai ekonomi, sehingga dapat meningkatkan kesejahteraan masyarakat, khususnya masyarakat desa Sukolilo.

\section{SIMPULAN}

Berdasarkan hasil dan pembahasan, maka kesimpulan mengenai kegiatan pengabdian masyarakat ini adalah sebagai berikut:

1. Sebagian besar peserta pelatihan dapat mengikuti setiap tahapan pelatihan yang diberikan dengan baik, namun ada beberapa tahap yangbelum terlaksana yaitu tahap pengembangan mengingat keterbatasan waktu

2. Kesejahateraan masyarakat desa Sukolilo meningkat melalui pemanfaatan limbah kertas menjadi kertas daur ulang yang kemudian diolah menjadi produk kreatif yang bernilai ekonomi. 
DAFTAR PUSTAKA

Suryana. 2009. Kewirausahaan: Pedoman

Praktis, Kiat, dan Proses Menuju Sukses.
Jakarta: salemba Empat.

Yahya Asep. 2005. Paper Craft. Jakarta: Pustaka Pembangunan Swadaya Nusantara. 